\title{
Blood Pressure in Inhabitants of High Altitude of Western Nepal
}

\author{
Shrestha $S,{ }^{1}$ Shrestha $A,{ }^{2}$ Shrestha $S,{ }^{3}$ Bhattarai $D^{4}$ \\ 'Department of Pediatrics, Patan Academy of Health Sciences, ${ }^{2}$ Department of General Practice and Emergency Medicine, \\ Patan Academy of Health Sciences, ${ }^{3}$ Nepal Eye Hospital, National Academy of Health Sciences, ${ }^{4}$ B P Eye Foundation, Kath- \\ mandu, Nepal.
}

\section{ABSTRACT}

Introduction: Studies conducted amongst the inhabitants of high altitude suggested that systolic and diastolic blood pressures are lower in the high than in low altitude population. So a study was designed to look at the blood pressure values among permanent residents of high altitudes of rural Western Nepal.

Methods: This is a descriptive cross sectional study conducted at two different altitudes (2670 and 2950 meters) of Humla District, Nepal, looking at the blood pressure values among the permanent inhabitants at these altitudes.

Results: Total number of 137 subjects with 73 (53.3\%) from 2950 meters and 64 (46.7\%) from 2670 meters altitude were enrolled. Mean age of the study population was 35.29 years. Male were 57 (41.6\%) and female 80 (58.4\%). The difference in systolic blood pressures (118.59 and $114.66 \mathrm{mmHg}$, $\mathrm{P}=0.01)$ and mean arterial pressures $(92.0$ and $89.5 \mathrm{mmHg}, \mathrm{P}=0.02)$ at the altitudes of 2670 and 2950 meters were statistically significant whereas the difference in diastolic BP at these altitudes were not statistically significant. There was no significant correlation of BMI with blood pressure values and no difference was noted in the blood pressure values among the two different ethnic groups at the given altitudes.

Conclusions: Lower rate of hypertension was observed among the inhabitants of high altitude of rural western Nepal. Blood pressure was found to decreases with increase in altitude among permanent inhabitants of high altitude.

Keywords: altitude; blood pressure; high altitude inhabitants; hypertension; physiological change.

\section{INTRODUCTION}

Systemic arterial pressure rises on acute exposure to high altitude and changes in blood pressure (BP) at high altitudes is attributed to increase in autonomic and sympathetic activity. ${ }^{1}$ More prolonged hypoxia of several days increases systemic pressure gradually, especially mean arterial BP and diastolic BP, in parallel with in- creases in plasma concentrations of norepinephrine. ${ }^{2}$ However, it has been reported that arterial BP is kept at normal ranges by enhanced vascularization resulting in decreased total peripheral resistance in adults liv-

Correspondence: Dr. Shrijana Shrestha, Department of Pediatrics, Patan Academy of Health Sciences, Lagankhel, Kathmandu, Nepal. Email: shri_rishi@hotmail.com 
ing in mountains for a long period. ${ }^{3}$ Studies conducted amongst the inhabitants of high altitude suggested that systolic and diastolic BP readings are lower in the high than in low altitude population, and when the residents of high altitude migrate towards the sea level, they show gradual elevation in BP. ${ }^{4}$

This study was designed to look at the BP values among permanent residents of high altitudes of Humla district, Nepal and to look at the BP differences at two different altitudes (2670 meters and 2950 meters) and in two different racial groups: Indo-Aryan and Tibeto-Burman, residing in the district.

\section{METHODS}

A descriptive cross sectional study was conducted at two different places of Humla District, Kirmi at an altitude of 2650 meters and Simikot at an altitude of 2970 meters from Dec $4-$ Dec 13, 2011. Adolescent and adults of either sex, who were residing permanently at the given altitudes, were enrolled after taking informed verbal consent. Personal details including age, sex and Body Mass Index (BMI) were recorded. Korotkoff sounds 1 and 5 were used to determine systolic and diastolic BP, respectively. BP reading was taken in both the arms with android sphygmomanometer using standard BP cuff and two readings were taken at the interval of 30 minutes. The mean of two BP readings on each arm was calculated and the higher of the two mean values was taken for analysis.

Hypertension was defined as more than or equal to $140 / 90 \mathrm{mmHg}$ for adult (as per JNC 7- Joint National Committee on Prevention, Detection, Evaluation, and Treatment of High Blood Pressure) and for adolescents $\mathrm{BP}$ reading of more than $95^{\text {th }}$ percentile for age and sex was defined as hypertension. ${ }^{5}$ Ethical clearance was taken from Institutional Review Board, Patan Academy of Health Sciences (IRB, PAHS). Data analysis was done using SPSS 16.0.

\section{RESULTS}

A total number of 137 subjects with 57 (41.6\%) male and $80(58.4 \%)$ female were enrolled in the study. Among them $73(53.3 \%)$ were from the altitude of 2950 meters and 64 (46.7\%) from the altitude of 2670 meters. Mean age of the study population was 35.29 years. Among the study cohort, 26 (19\%) were adolescents (14-21years), 111 (81\%) were adults.

Mean BMI of all the study subjects was $21.37 \mathrm{Kg} / \mathrm{m}^{2}$. The mean BMI of male and female at 2950 meters were $19.46 \mathrm{Kg} / \mathrm{m}^{2}$ and $21.03 \mathrm{Kg} / \mathrm{m}^{2}$ respectively $(P=0.01)$ while at 2670 meters the mean $\mathrm{BMI}$ of male and female were $23.01 \mathrm{Kg} / \mathrm{m}^{2}$ and $21.96 \mathrm{Kg} / \mathrm{m}^{2}$ respectively $(P=0.01)$. BMI at 2950 meters was lesser than that of 2670 meters $\left(20.43 \mathrm{Kg} / \mathrm{m}^{2}\right.$ vs. $\left.22.43 \mathrm{Kg} / \mathrm{m}^{2} ; \mathrm{P}=0.01\right)$. In females the difference in $\mathrm{BMI}$ was not statistically significant $(\mathrm{P}=0.06)$.

The mean arterial pressure (MAP) on right and left arms were 90.70 and $90.24 \mathrm{mmHg}$ respectively $(P=0.2)$. Mean Systolic BP of the study subjects on right arm was $116.50 \mathrm{~mm} \mathrm{Hg}$ and on left arm was $116.13 \mathrm{mmHg}$ $(P=0.6)$. Mean diastolic BP on right arm was 77.81 $\mathrm{mmHg}$ and on left arm was $77.30 \mathrm{mmHg}(P=0.1)$. Though, the higher of the two arm BP readings were taken for analysis, there was no statistically significant difference between right and left arm BP values.

The mean values of MAP, systolic and diastolic BPs at the altitude of 2650 meters were 92.0, 118.59 and $78.75 \mathrm{mmHg}$ respectively; while at the altitude of 2970 meters the values were 89.5, 92.0 and $76.99 \mathrm{mmHg}$ respectively (Table 1 ).

Table 1. Blood pressure in relation to altitude.

\begin{tabular}{llllll}
\hline & $\begin{array}{l}\text { Altitude } \\
\text { (meters) }\end{array}$ & $\mathrm{N}$ & Mean & $\mathrm{P}$ \\
\hline $\begin{array}{l}\text { Mean Arte- } \\
\text { rial Pressure } \\
\text { (mmHg) }\end{array}$ & 2950 & 73 & 89.5 & 0.02 \\
\hline $\begin{array}{l}\text { Systolic BP } \\
\text { (mmHg) }\end{array}$ & 2670 & 64 & 92.0 & \\
\hline $\begin{array}{l}\text { (mmHo } \\
\text { Diastolic BP }\end{array}$ & 2670 & 64 & 118.59 & 114.66 & \\
\hline (mmHg) & 2650 & 73 & 76.99 & \\
\hline
\end{tabular}

Statistical significant difference was noted only for MAP and systolic BP at the two different altitudes. Increase in MAP was seen in both adult and adolescents with increase in altitude. An increase in systolic pressure and decrease in diastolic pressure was seen in adolescents but a decrease in systolic pressure and increase in diastolic pressure was seen in adults with the increase in 
altitude (Table 2). No significant difference in BP values was noted in the two ethnic group (Indo- Aryan and TibetoBurman) populations residing at the given altitudes of 2650 and 2970 meters (Table 3). Significant differences in BP values were observed in both the sexes at the two different altitudes (Table 4).

Table 2. Blood pressure in relation to age category and altitude.

\begin{tabular}{|c|c|c|c|c|c|}
\hline Age Category & $\begin{array}{l}\text { Altitude (me- } \\
\text { ters) }\end{array}$ & $\begin{array}{l}\text { Systolic BP } \\
(\mathrm{mmHg})\end{array}$ & $\begin{array}{l}\text { Diastolic BP } \\
(\mathrm{mmHg})\end{array}$ & $\begin{array}{l}\text { MAP } \\
(\mathrm{mmHg})\end{array}$ & $P$ value \\
\hline Adolescence & 2950 & 111.58 & 73.68 & 88.64 & \multirow{2}{*}{$<0.05$} \\
\hline $14-21$ years & 2670 & 107.14 & 75.71 & 84.64 & \\
\hline \multirow{2}{*}{$\begin{array}{l}\text { Adult } \\
>21 \text { years }\end{array}$} & 2950 & 114.00 & 76.57 & 89.04 & \multirow{2}{*}{$<0.05$} \\
\hline & 2670 & 115.67 & 75.33 & 87.66 & \\
\hline
\end{tabular}

Table 3. Blood pressure in relation to altitude and major ethnic group of the area.

\begin{tabular}{llllll}
\hline $\begin{array}{l}\text { Altitude } \\
\text { (meters) }\end{array}$ & $\begin{array}{l}\text { Ethnic } \\
\text { Group }\end{array}$ & $\begin{array}{l}\text { Systolic BP } \\
(\mathrm{mmHg})\end{array}$ & $\begin{array}{l}\text { Diastolic BP } \\
(\mathrm{mmHg})\end{array}$ & $\begin{array}{l}\text { MAP } \\
(\mathrm{mmHg})\end{array}$ & $\begin{array}{l}\text { P value (Between and } \\
\text { within the group) }\end{array}$ \\
\hline \multirow{2}{*}{2950} & $\begin{array}{l}\text { Indo-Aryans } \\
\text { Tibeto-Bur- } \\
\text { man }\end{array}$ & 113.23 & 76.45 & 88.70 & 0.08 \\
& $\begin{array}{l}\text { Indo-Aryans } \\
\text { Tibeto-Bur- }\end{array}$ & 115.71 & 77.38 & 90.15 & 0.3 \\
\hline
\end{tabular}

Table 4. Blood pressure in relation to sex and altitude.

\begin{tabular}{llllll}
\hline Sex & Altitude (meters) & Systolic BP $(\mathrm{mmHg})$ & Diastolic BP $(\mathrm{mmHg})$ & MAP $(\mathrm{mmHg})$ & $P$ value \\
Male & 2950 & 117.86 & 77.14 & 90.71 & $<0.05$ \\
& 2670 & 131.38 & 83.10 & 98.04 & 88.81 \\
Female & 2950 & 112.67 & 76.89 & 87.04 & $<.05$ \\
\hline
\end{tabular}

\section{DISCUSSION}

Hypertension was observed in $3.77 \%$ of our study population and this value is comparable to the reported prevalence of $2 \%$ hypertension in rural areas of Asian countries. ${ }^{6}$ The prevalence of hypertension and mean systolic and diastolic BPs varied from one country to another country and from one community to another community in the same country depending upon the economic development and affluence. ${ }^{7}$ Furthermore, elevated BP was more prevalent among urban high altitude inhabitant than rural high altitude inhabitant. BMI and age is said to be a strong predictor of high systolic and diastolic BP amongst the inhabitant of high altitude. ${ }^{8}$ In our study, sample was taken from two areas with difference in altitude but with similar mixture of ethnic in- habitants of comparable economic backgrounds. Hence the differences in BP values observed between the two areas could be attributed to change in altitude.

High-altitude environments imply stress factors such as hypoxia, cold, humidity, solar radiation, cosmic radiation, and exposure to high-altitude causes many physiological and biochemical changes in man. ${ }^{9}$ MAP, systolic and diastolic BPs, in our study population, decreased with increase in altitude. However this change was not statistically significant for diastolic BP. A study by Ruiz and Penazola suggested that residents at higher altitude have lower resting BP, especially systolic BP which is consistent with our study. ${ }^{10}$ Similar findings were also noted in a study done among Tibetan children and adolescents at high altitude. ${ }^{11}$ The cause of decline in BP at high altitude has been attributed to relaxation of smooth muscle, an increase in collateral circulation, increase in 
vascularisation and higher hemoglobin level. ${ }^{12}$

BP is multi factorial and is influenced by many lifestyle variables like diet, nutrition, physical activity, smoking, alcohol and mental stress. ${ }^{13}$ Hypertension has been reported to be frequent in Tibetans and this was attributed to over-consumption of salt and yak butter. ${ }^{14}$ We did not find difference in the BP values among the two different ethnic groups at the given altitudes. We observed increase in BP with age at both of the study altitudes. No clear relation of BMI with high BP was noted at the study altitudes. Other measure of adiposity like skin fold thickness and hip to waist ratio could have been considered to get the exact picture. In a study performed in Arabia, it was found that BP in people living at high altitudes was higher, and this was attributed to higher BMI and polycythemia. ${ }^{15}$

We observed that BP values significantly decreased at higher altitude in males but there was increment in BP among females at higher altitude. The possible hypothesis could be the difference in level and quality of activities amongst male and female in these areas of rural $\mathrm{Ne}$ pal. Besides, hormonal factors could have roles to play. There are various studies showing increase in BP with acute exposure to high altitude and degree of decline in BP is a function of length of time of residence at high altitude. ${ }^{16}$ As our study population has been permanently staying at high altitude, systemic hypertension was encountered only in smaller number of subjects and a marginal decrease in BP with change in altitude was observed. The possible hypothesis at the molecular level

\section{REFERENCES}

1. Rhodes HL, Chesterman K, Chan CW, Collins P, Kewley E, Pattinson KT, et al. Systemic blood pressure, arterial stiffness and pulse waveform analysis at altitude. Journal of the Royal Army Medical Corps. 2011;157(1):110-3.

2. Wolfel EE, Selland MA, Mazzeo RS, Reeves JT. Systemic hypertension at $4,300 \mathrm{~m}$ is related to sympathoadrenal activity. J Appl Physiol. 1994;76(4):1643-50.

3. Pocock G, Richards CD. Human physiology : the basis of medicine. Oxford: Oxford University Press; 1999. p. 591-8.

4. Hanna JM. Climate, altitude, and blood pressure. Human biology. 1999;71(4):553-82.

5. Chobanian AV, Bakris GL, Black HR, Cushman WC, Green LA, Izzo JL, Jr., et al. The Seventh Report of the Joint National Committee on Prevention, Detection, Evaluation, and Treatment of High Blood Pressure: the JNC 7 report. JAMA : the journal of the American Medical Association. 2003;289(19):2560-72. may be the presence of Nitric oxide causing vasodilatation. ${ }^{17}$ The hypothesis has been tested and proved for pulmonary hypertension in animal module but this may be the factor playing part in systemic pressure as well. The sample size of the study was small and the age range was wide which gives a caution to draw definite conclusions and the results may not represent the whole population which is a limitation of our study. The difference between the two study altitudes was narrow and may not be enough to study the impact of change in altitude on BP values.

\section{CONCLUSIONS}

There have not been any published literatures on BP values in permanent residents of high altitudes of Nepal. This study highlights the lower rates of hypertension at high altitudes of rural western Nepal. Among the high altitude inhabitants, a marginal decrease in BP was observed with increase in altitude. No difference in BP values was observed between two different ethnic group populations and no clear correlation of BP and BMI at the study altitudes was observed. This statement however needs to be verified with a larger study conducted at different locations and altitudes and different ethnic populations.

\section{ACKNOWLEDGEMENTS}

Acknowledgements: PSSN (Professional Support Service Nepal) and ISIS foundation (International Development Organization) for logistic support

6. Gupta R. Meta-analysis of prevalence of hypertension in India. Indian heart journal. 1997;49(4):450.

7. Sharma SK, Ghimire A, Radhakrishnan J, Thapa L, Shrestha NR, Paudel N, et al. Prevalence of hypertension, obesity, diabetes, and metabolic syndrome in Nepal. International journal of hypertension. 2011;2011:821971.

8. Smith C. Blood pressures of Sherpa men in modernizing Nepal. American journal of human biology : the official journal of the Human Biology Council. 1999;11(4):469-79.

9. Kumar R, Qadar Pasha MA, Khan AP, Gupta V, Grover SK, Norboo T, et al. Association of high-altitude systemic hypertension with the deletion allele-of the angiotensinconverting enzyme (ACE) gene. International journal of biometeorology. 2003;48(1):10-4

10. Ruiz L, Penaloza D. Altitude and hypertension. Mayo Clinic proceedings Mayo Clinic. 1977;52(7):442-5.

11. Tripathy V, Gupta R. Blood pressure variation among Tibetans at different altitudes. Annals of human biology. 2007;34(4):470-83. 
12. Leon-Velarde F, Sanchez J, Bigard AX, Brunet A, Lesty C, Monge C. High altitude tissue adaptation in Andean coots: capillarity, fibre area, fibre type and enzymatic activities of skeletal muscle. Journal of comparative physiology B, Biochemical, systemic, and environmental physiology. 1993;163(1):52-8.

13. Stamler J. Blood pressure and high blood pressure. Aspects of risk. Hypertension. 1991;18(3 Suppl):I95-107.

14. Sun SF. Epidemiology of hypertension on the Tibetan Plateau. Human biology. 1986;58(4):507-15.
15. Khalid ME, Ali ME, Ahmed EK, Elkarib AO. Pattern of blood pressures among high and low altitude residents of southern Saudi Arabia. Journal of human hypertension. 1994;8(10):765-9.

16. Marticorena E, Ruiz L, Severino J, Galvez J, Penaloza D. Systemic blood pressure in white men born at sea level: changes after long residence at high altitudes. The American journal of cardiology. 1969;23(3):364-8.

17. Koizumi T, Ruan Z, Sakai A, Ishizaki T, Matsumoto T, Saitou M, et al. Contribution of nitric oxide to adaptation of tibetan sheep to high altitude. Respiratory physiology \& neurobiology. 2004;140(2):189-96. 